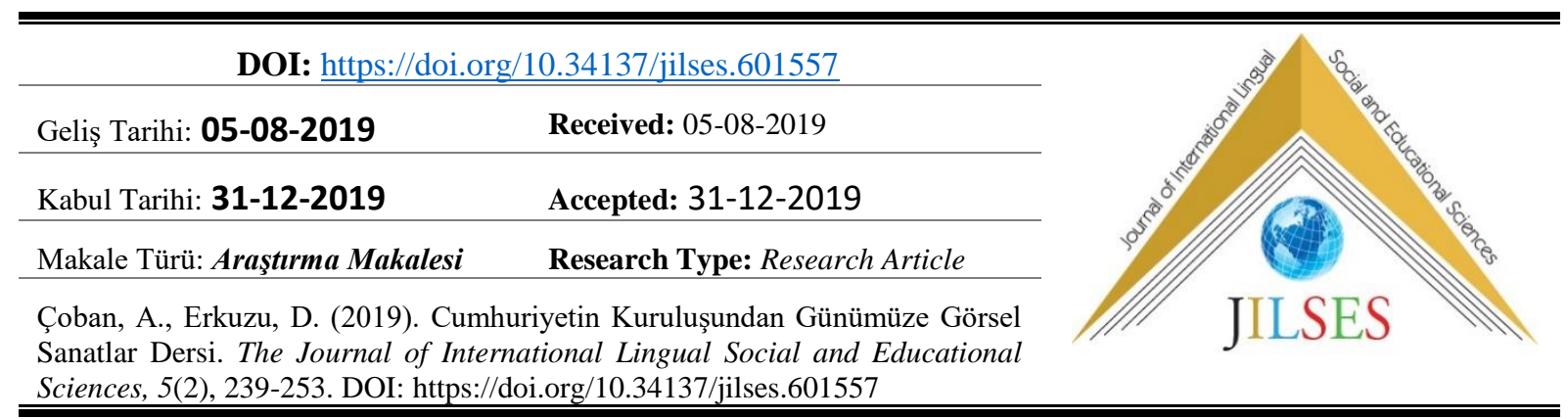

\title{
Cumhuriyetin Kuruluşundan Günümüze Görsel Sanatlar Dersi*
}

\section{Ahmet ÇOBAN', Demet ERKUZU²}

$\ddot{O} z$

Sanat eğitiminin bireyin gelişimindeki gerekliliği, yaratıcılı̆̆a olan etkisi, psikomotor, bilişsel ve duyuşsal alanlarda gerçekleştirilen kazanımlara olan katkısı oldukça önemlidir. Sanat eğitiminde; sanatın bireye sağladığ kültürel ve toplumsal katkılarının yanı sıra, kendine güveni olan, yeteneklerini ortaya çıkaran, çevreye duyarl ve estetik duygularını geliştiren bireylerin gelişimine önem verilmektedir. Bu çalışmada; Türk Ĕ̈itim Sistemi'nde (1924 - 2018 Arasl) yer alan Görsel Sanatlar dersi ögretim programlarl ile ilgili gelişmelerin değerlendirilmesi amaçlanmıştır. Araştırmada nitel araştırma yaklaşımı benimsenmiş, araştırmanın modeli, kaynak tarama yöntemidir. Araştırmada, 1924-2018 yılları arasındaki Görsel Sanatlar dersi ögretim programları taranmış ve görsel sanatların değişen ad, hangi sınıflarda yer aldiğl, amaçları, kazanımları, ders saati sayısı ile ilgili geliş̧meler ve görsel sanatların programlardaki ağırlı̆̆ değerlendirilmiştir. Araştırmada tarama modeli kullanıldiğından evren ve örneklem belirtilmemiștir. Elde edilen bulgularda; Programlarda dersin adında değişiklikler yapıldığı, Görsel sanatlar dersine her sınıf düzeyinde yer verildiği, ders saatinin zamanla azaldı̆̆g, programlarda amaçlara yer verildiği ve hedef sayısının arttı̆̆ belirlenmiştir. Kazanımlara ilk olarak 1992 İlköğretim Resim-İş dersi Öğretim Programında yer verildiği ve daha sonraki programlarda ögrenme alanlarına ayrılarak yapılandırlldı̆̆ belirlenmiş ve dersin programlardaki ă̆ırlı̆̆ını zamanla azalmıştır. Görsel Sanatlar dersinin programlarda belirlenen amaçlara ulaşılabilmesi için önerilere yer verilmiştir.

Anahtar Kelimeler: Ders, Görsel Sanatlar, Öğretim Programı, Haftalık Ders Çizelgesi.

\section{From the Establishment of the Republic to the Present Visual Arts Subject}

\begin{abstract}
The contribution of art education to the necessity in the development of the individual, its impact upon creativity, and its contribution to the achievements which are realized in psychomotor, cognitive and affective fields are quite crucial. In art education besides the cultural and social contributions of art to the individual, the development of individuals who are self-confident, revealing their talents, develop their environmentally sensitive and aesthetic feelings are given importance. In this study; The aim of this subject is to evaluate the developments in the Visual Arts curriculum in the Turkish Education System (1924 - 2018). Qualitative research approach is adopted in the research and the research model is the source scanning method. In this research, Visual Arts subject programs between 1924-2018 were scanned and the changing name of the visual arts, in which classes it took place, aims, achievements, developments related to the number of subject hours and the weight of visual arts in the programs were evaluated. Since the survey model was used in the study, the universe and sample were not specified. According to the findings; It has been determined that the name of the subject has been changed in the programs, Visual arts subject has been included in every grade level, the hours of the subject have decreased, the goals have been included in the programs and the number of targets has increased. It was determined that the gains were first included in the 1992 Elementary Art Teaching Program and then structured into learning areas and later the weight of the subject in the programs decreased. Suggestions have been made in order to achieve the objectives determined in the Visual Arts subject.
\end{abstract}

Keywords: Lesson, Visual Arts, Curriculum, Weekly Subject Schedule.

\footnotetext{
* Bu araştırma; ilk yazarın danışmanlığında, ikinci yazarın “Görsel Sanatlar Öğretim Programları İle İlgili Gelişmelerin Değerlendirilmesi (1924-2018 Arası)" başlıklı yüksek lisans tezinin bir bölümüne dayalı olarak hazırlanmıştır.

${ }^{1}$ Doç. Dr., Dicle Üniversitesi, Eğitim Fakültesi, ahcoban@gmail.com, Orcid:0000-0002-8177-5670

2 Öğr. Gör., Sosyal Bilimler Meslek Yüksekokulu, demet.erkuzu56@gmail.com, Orcid: 0000-0001-5041-0380
} 


\section{Giriş}

Eğitimin bütün planlanmış faaliyetleri, belirli amaçlara ulaşabilmek ve bazı işlevleri gerçekleştirebilmek içindir. Eğitim sistemlerinin dayandığı belirli bir eğitim felsefesi, bu felsefeye göre teorik olarak yetiştirilmesi tasarlanan bir insan tipi ve oluşturulması istenilen bir toplum modeli vardır. Eğitim felsefesinin içinde eğitimin amaç ve işlevleri yer alır. Eğitimin amaçları, durağan bir yapıda olmayıp değişen beklenti ve ihtiyaçlara göre yeniden yorumlanmak ve belirlenmek durumundadır (Şişman, 2018: 27). Bunun için ilk insandan günümüze kadar eğitimin önemi ve nasıl olması gerektiği konusu toplumların, devletlerin ve kurumların öncelikli görevi olmuştur.

Eğitim, çevre ve zaman bakımından geniş kapsamlı, sürekli ve ayrıca çok yönlüdür (Gürkan ve diğ, 1998: 10). Eğitim zaman, çevre, ortam ve mekan yönünden sınırlandırılamaz. Eğitim toplumun en kapsamlı ve en geniş faaliyetlerinden biridir. İnsan yaşamı boyunca eğitim ile beraber ve iç içedir (Fidan, 2012: 7). Günümüz eğitim sistemimizden beklenilen, sadece belirli bilgi ve becerilerin öğrencilere kazandırılması değildir. Bireyin bunlardan değişik sentezlerle farklı ürünler, farklı fikirler ortaya çıkarabilme yeteneğinin geliştirilmesi ve kazandığı bu davranışları gerektiği zaman ve yerlerde uygulayabilmesidir. Sanatta yaratıcılık kavramını açıklayan bu davranış biçimi ile dünyayı algılayabilmek ve gerekli alışkanlıkları edinebilmenin bir yolu da sanattan geçmektedir (Ayaydın ve diğ. 2011: 13). Sanat, bir düzenleme, bir sezgi olayıdır. İçten ve dıştan gelen çeşitli baskının, etkinin (toplumsal- ruhsal ideal ve değerlerin) en iyi yol ile ortaya çıkardığı, estetik niteliklere sahip, özgün bir üründür (Artut, 2013: 20). Sanatın insan eğitime, gelişimine ve yaratıcılık yeteneğine olan etkisi oldukça önemlidir. Sanat eğitimi ile amaçlanan, her bireyi yaratıcılığa yönlendirip bakış açısını geliştirmek ve görsel zekasını geliştirerek yorum ve çıkarımlar yapabilmesini kazandırmaktır.

İnsan çok yönlü ve eğitim gereksinimi olan bir varlıktır. İnsan eğitimin de başlıca yön ve bileşenlerden biri sanat eğitimidir. Sanat eğitimi bilim, felsefe, teknik ve kinestetik alan eğitimleri ile birlikte bireysel ve toplumsal eğitimin en vazgeçilmezlerinden biridir (Mercin ve Alakuş, 2007: 15 ). Sanat insanın sadece aklına değil yüreğine de seslendiği için her alanda uygulanmakta ve çocukların gelişim aşamalarına uygun olarak verilmesi, özellikle örgün eğitim sisteminde önemli yer tutar (Akkurt ve Boratav, 2018: 55) Sanat eğitimi tüm öğrenme biçimlerini (duyuşsal, kinestetik, görsel, bilişsel) desteklemektedir. Çünkü sanat öğretimi; öğretici ile öğrenen (öğretmenöğrenci) arasında daha önceden programlanmış estetiksel etkinlikler çerçevesinde oluşan amaçlı, anlamlı iletişim ve etkileşimlerle gerçekleşir (Artut, 2013: 100).

Sanat eğitimi, tanım olarak sanat ve bilim çevrelerinde benimsenmiş görünse de, terimin kavram ve kapsam olarak tam yerine oturduğu söylenemez. Çünkü bugüne kadar bu terim yerine ya da alanı belirlemeye yönelik kullanılan terimler oldukça fazladır (Resim-iş, güzel sanatlar eğitimi, sanat yoluyla öğretim, estetik eğitimi, plastik sanatlar eğitimi, görsel sanatlar eğitimi, sanata doğru eğitim, sanat öğretimi, temel sanat eğitimi vb.). Sanatın eğitimi ile veya sanatı konu alan eğitimle ilgili olarak oldukça fazla sayıda olan bu kavramlar, zaman zaman kavram kargaşalarına da zemin oluşturmakta ve zihinleri karıştırmaktadır (Yolcu, 2018: 75). Sanat eğitimini Yolcu; (2018: 77) "Kişinin duygularını, düşüncelerini, izlenimlerini, yetenek ve yaratıcılığını estetik bir düzeye ve bu düzeyde bir anlatıma ulaştırabilmek amacıyla yapılan eğitim faaliyetlerinin tümü” olarak tanımlamıştır.

\section{Eğitim Programı:}

Eğitim programı, okulda bireye kazandırılması amaçlanan özellikleri ve bu özellikleri kazandırıcı nitelikteki eğitim durumlarını, yaşantılar sonucundaki davranışların derecesini anlamaya yarayacak sınama durumları ve sınama sonucunda elde edilen verilerle yapılacak değerlendirmeyi içeren tasarıdır (Aşılıoğlu, 2014: 20). Eğitim sisteminin ana parçalarından biri eğitim programlarıdır. Ülkenin gelişimi ile beraber öğretim programlarının da zamanın beklenti ve ihtiyaçlarına uyum sağlaması gerekir. Çünkü sosyo - kültürel, bilimsel ve teknolojik gelişmeler doğrultusunda nitelikli insan gücüne ihtiyaç vardır ve eğitim-öğretim programlarının geliştirilip uygulanması ile mümkün olabilir (Tan, 2006; Akt. Gültekin, 2017: 14). Eğitim programları öğrencilerde kazandırılması istenilen planlar olduğundan sistemin ulaşmak istediği hedefleri belirler (Tan ve Erdoğan, 2004: 7). Eğitim programları günümüze uygun, bireyin ihtiyaçlarına cevap veren bir yapıda hazırlanmalıdır.

\section{Eğitim Programını Oluşturan Öğeler:}

Eğitimde program geliştirme süreci program öğeleri olan hedef, içerik, öğrenme-öğretme süreci ve değerlendirme boyutları arasındaki dinamik ilişkiler bütünüdür (Demirel, 2015: 95).

Hedef: Eğitimde bireyleri "Niçin eğitiyoruz?" sorusuna cevap arar. Öğretim programının uygulanmasıyla ulaşılmak istenilen noktayı ifade eder. Öğrencilere kazandırılmak üzere belirlenmiş eğitim yoluyla kazandırılabilir istendik özellikler ya da yeterliliklerdir. Bu özellikler; bilgiler, beceriler, yetenekler, tutumlar, ilgiler, alışkanlıklar vb. davranışlar olabilir (Akpınar, 2017: 116). Hedeflerde; Öğrenciye Görelik, Açıklık (Anlaşılırlık), Öğrenme Ürününe Dönüklük, Ulaşılabilirlik, Genellik ve Sınırlılık, Tutarlılık (Kaynaşıklık), Kenetlilik (Konu Alanı İle İlişkili Olma), Bitişiklik gibi nitelikler bulunmalıdır (Akpınar, 2017: 122-123). 
İçerik: Üzerinde durulacak konu veya gerçekleştirilmesi öngörülen etkinliklerdir (Şişman, 2018: 11). Programda "Ne öğretelim?" sorusunun cevabıdır. Öğrenme-Öğretme sürecinde öğrencilerin kazanacakları bilgiler, içeriği oluşturur. Program içeriği, ünite ve konuların hedef davranışları kazandıracak biçimde belirlenmesi ve düzenlenmesidir (Akpınar, 2017: 140).

Eğitim Durumları: Öğrenme-öğretme süreci, yaşantılar ve işlemler olarak ifade edilebilir. Bu öğe, "Nasıl öğretelim?" sorusuna cevap arar. Eğitim durumları, öğrencilerin hedefe ulaşması için geçirmeleri gereken öğrenme yaşantılarını sağlayacak dış koşulların (uyarıcıların) düzenlenmesi ve uygulanmasını kapsar. Bu düzenleme, öğrencinin, içeriği oluşturan bilgilerle etkileşimini sağlamak için gerekli olan öğretim stratejisi, tekniği, yöntemi ile bunlara destek verecek fiziki düzenlemeleri, araç-gereçleri ve bunlarla ilgili her türlü etkinlikleri kapsar (Akpınar, 2017: 158). Eğitim durumunda hedeflere uygun olarak, bilgi sahibi olmayan öğrenciyi bilen, ilgi-tutum sahibi olmayan öğrenciyi ilgi duyan, tutum kazanmış, beceri sahibi olmayan öğrencinin becerili hale gelmesi için uygun öğrenme - öğretme etkinlikleri düzenlenmektedir (Şeker ve diğ. 2014: 12).

Sınama Durumları (Ölçme ve Değerlendirme): Öğretim programında “Ne kadar?" ve "Ne düzeyde?" sorularına cevap verir. Ölçme, değerlendirme ve durumları belirleme etkinliklerini kapsar. Sınama durumları, öğretim programının uygulanması ile öğrencilerin öngörülen hedef davranışları (kazanımları) ne düzeyde kazandıkları hakkında yargıya varma sürecidir (Akpınar, 2017: 168). Düzenlenecek değerlendirme/sınama durumlarının, eğitimde ölçme ve değerlendirmede söz edilen ilkeler kapsamında bilişsel, devinimsel ve duyuşsal düzeylerde belirlenen hedefleri ölçülebilecek bir nitelikte olması gereklidir (Şişman, 2018: 12).

\section{Sanat Eğitimi}

Sanat eğitimi çocuğun kendini özgürce ifade edebildiği bir ortamdır. Çocuğun kişiliğinin gelişmesinde, kendine güvenmesinde önemli rol oynar. Atölye derslerinde paylaşma, sorumluluk, düzen, malzemeyi kullanma konularında bilinçlenir. Sanat eğitimi, özgür, insancıl, barış̧̧ı, yaratıcı, toplumu ile bütünleşmiş, değişen şartlara göre kendini yenileyebilen, geleceğin izlerini yansıtan çocukların yetişmesi için vazgeçilmez bir dünyadır. Sanat eğitimi çocuklara, kültür, tarih ve sanat değerlerini kazandırırken aynı zamanda onların özgürce yaratıcı düşüncelerini ortaya koyabilecekleri bir süreç olmalıdır ( Buyurgan ve Buyurgan, 2012: 11). Sanat eğitiminin amaç ve gerekliliğinin yanında bireylerin ruhsal gereksinmelerinin doyurulması, insan ruhunun yüceltilmesi, insanın özgürleşmesi, çağdaş, dengeli, duyarlı bir toplum yaratılması çabası güdülür. Sanat eğitimi, bireylere özgür anlatım olanakları sağlar. Ayrıca, bireyin sosyokültürel yaşamının, kişisel deneyimlerinin sübjektif ve ayrıntılı bir alanıdır Sanat eğitimi, genel düzeyleri nasıl olursa olsun tüm toplum ve ülkeler için kaçınılmaz bir gereksinimdir. Hızla gelişen, sanayileşen, kentleşen toplumların bireylerinde görülen ruhsal rahatsızlıkların arttığı ve bunların kökeninde makineleşmenin yarattığı, tekdüze hızlı yaşam ve elektronik cihazların egemen oluşu, kişilerin deşarj olma olanaklarını kısıtlayabilmektedir. Sanata ilişkin en önemli özellik anlatımdır. Kişinin öznel iç görüşü, imgeleri, düşünceleri ve duyuları sanat ile görselleşir. Bu durumun dışa dönüşmesi, somutlaşması ve başkalarına anlatması insan için gereksinimdir. Hangi sanat yapıtı olursa olsun yaratma eylemi, anlatılmak isteneni izleyiciye iletme amacı güder. Sanat eğitiminin ana amacı; öğrenciyi, kapasitesi doğrultusunda entelektüel, duygusal ve sosyal gelişme açısından destekleyerek onun kişisel istemlerine yanıt verebilme çabasını hedefler (Artut, 2013: 121-122).

\section{Görsel Sanatlar Eğitimi}

Görsel sanatlar eğitimi, okul öncesi döneminden üniversiteye kadar uygulanan örgün; aynı zamanda bireylerin boş zamanları değerlendirme ve bir hobi alanı olarak ta yaygın olarak özel ve devlet sanat galerilerinde, müzelerde, iletişim ve bilgi çağı olarak nitelenen 21. yüzyılın en önemli eğitim alanlarından biridir (Özsoy, 2015: 2). Görsel sanatlar birçok alanı kapsamaktadır. Bunlar; resim, mimarlık, heykel, uygulamalı sanatlar, grafik sanatlar, bilgisayar sanatı, moda tasarımı, uygulamalı sanatlar gibi oldukça geniş bir alanı kapsar. Bütün dallarla ilgili olarak okul öncesinden yükseköğretime kadar her aşamada sanat eğitimi ve öğretimiyle ilgili uygulamalı ve kuramsal çalışmalara "görsel sanatlar eğitimi” veya "sanat eğitimi” denilmektedir (Kırışoğlu, 2005: 2).

Görsel sanatlar yaşantılarımıza canlılık verir, bizi hassaslaştırır ve neye inandığımıza, kim olduğumuza, ilgilerimizi, kendimizi ve toplumumuzu aynaya yansıtmamızı sağlar. Görsel sanatlar, her bireyin özgünlügüyle, benzersizliğiyle kişilikli birey olmanın yüceliği ile ve yaratıcı hayaller kurma ile ilgilenir (Özsoy, 2015: 31). Sanat alanındaki yaratıcılıkta gerekli olan yetenekler bilim ve teknikteki yaratıcılıklarda da geçerlidir. Gelişmiş ülkeler okul öncesi dönem ile birlikte sanat eğitimine ağırlık verip, bireyi her türlü yaratıcılığa hazırlamaktadır. Küçük yaşlardan itibaren örgün eğitimde verilen sanat eğitimi, yaratıcılığı geliştirirken estetik bir düzey, iyiyi, güzeli, doğruyu seçebilme, karar verebilme ve kritik yapabilme becerisini beraberinde getirecektir (Ünver, 2002: 23-24).

Görsel sanat eğitimiyle ulaşılmak istenen üç temel eğitimsel hedef şöyle ifade edilebilir (Ayaydın ve diğ. 2011: 16): 
- Görsel sanatlar eğitimi alan öğrenciler; farklı toplumların ve kültürlerin tarihi gelişimlerini veya günümüzdeki sanat eserlerini analiz ederek, bunları içerik olarak değerlendirmeyi öğrenme.

- Ö̈̆rencilere görsel sanat eserlerini incelerken, eserlere eleştirel ve analitik düşüncelerle bakmayı, evrensel ve yerel sanatlar hakkında farklı anlam ve içerikleri tanımlamayı öğrenme,

- Öğrencilerin sanat uygulamaları ile ilgili yeni fikirler üreterek bunları geliştirmeleri, farklı araç-gereçler kullanarak ürüne dönüştürmeyi öğrenme.

\section{Araştırmanın Amacı}

Araştırmanın amacı, Türk Eğitim Sisteminde Cumhuriyetten günümüze kadar, Görsel Sanatlar Dersi ile ilgili hangi boyutlarda ne tür gelişmelerin olduğunun saptamaktır. Bu temel amaç çerçevesinde, aşağıdaki sorulara cevap aranmıştır:

\section{Görsel Sanatlar Dersinin}

1.İsmi,

2.Hangi sınıf düzeylerinde yer aldığı,

3.Amaçları,

4.Kazanımları,

5.Süresi,

6.Öğretim programlarındaki ağırlığı ile ilgili gelişmeler nelerdir?

\section{Sinırlılıklar}

$\mathrm{Bu}$ araştırma;

- Cumhuriyetten Günümüze (1924 - 2018) İlkokul, Ortaokul ve İlköğretim Görsel Sanatlar ( Resim-İş ) dersi öğretim programları ile sınırlıdır.

- Milli Eğitim Bakanlığı'nın Kütüphanesinden ulaşılan Öğretim programları, Milli Eğitim Bakanlığı Talim ve Terbiye Kurulu Başkanlığı internet sitesinde yayınlanan Görsel Sanatlar Dersi öğretim programı (İlköğretim) ve haftalık ders çizelgeleri, kitap olarak basılmış olan öğretim programları ile sınırlıdır.

- $\quad$ Programların amaçları, kazanımları ve haftalık ders saati çizelgeleri ile sınırlıdır.

\section{Yöntem}

Araştırmada, nitel araştırma deseni benimsenmiş, araştırma verileri doküman incelemesi yoluyla toplanmıştır. Doküman incelemesi, nitel araştırmalarda etkili bir şekilde kullanılması gereken önemli bilgi kaynaklarıdır. Araştırılması hedeflenen olgu veya olgular ile ilgili bilgi içeren yazılı materyallerin analizini kapsamaktadır (Yıldırım ve Şimşek, 2016: 189).

\section{Verilerin Toplanması}

Araştırma verileri doküman incelemesi yoluyla toplanmıştır. Dokümanlar, nitel araştırmalarda üçüncü ana veri toplama kaynağı olarak bireysel yazılar, popüler kültür dokümanları, toplumsal kayıtlar, fiziki materyaller ve görsel dokümanlar sanat eserleri olarak tanımlanır (Merriam, 2015: 154). Araştırmada verileri toplamak için, nitel araştırma yöntemleri kapsamında doküman analizi kullanılmıştır. Araştırmada Milli Eğitim Bakanlığı’nın Kütüphanesinde ulaşılan Öğretim programları, Milli Eğitim Bakanlığı Talim ve Terbiye Kurulu Başkanlığı internet sitesinde yayınlanan Görsel Sanatlar Dersi öğretim programı (İlköğretim) ve haftalık ders çizelgeleri, kitap olarak basılmış olan öğretim programları değerlendirilmiştir.

$\mathrm{Bu}$ araştırmanın alanyazın çalışması olarak öncelikle alanyazın taraması ve kaynakça taraması yapılarak gerçekleştirilmiştir. Araştırmada, İlkokul (1924, 1926, 1930, 1948, 1968), Ortaokul (1930, 1938, 1949, 1970) ve İlköğretim (1992, 2006, 2013, 2018) öğretim programlarındaki Görsel Sanatlar (Resim-İş) dersi verileri değerlendirilmiştir. Verilerin toplanmasında MEB yayınları, MEB Talim Terbiye Kurulu Başkanlığı'nın internet sitesindeki ilköğretim haftalık ders çizelgeleri ve Ankara İlindeki kütüphaneler taranmıştır. İlgili kaynaklar taranmış, İlgili çizelgeler tutulmuş ve sonuçlar incelenmiştir. Elde edilen veriler, program öğelerinin değerlendirilmesi kapsamında analiz edilmiştir. Millî Eğitim Bakanlığı Tebliğler Dergisi’nin Ekim 2006-2589 sayısında, 11.09.2006 tarih ve 351 sayılı kararı ile Talim ve Terbiye Kurulu Başkanlığının 11.09.1992 tarih ve 287 sayılı kararı ile kabul edilen “İlköğretim Resim-İş (1-8. sınıflar) Dersi Programı’nın, 2006-2007 Öğretim yılından itibaren 1, 2, 3, 4, 5, 6. sınıflardan itibaren kademeli olarak uygulamadan kaldırılması kararlaştııılmış ve bu dersin 
yerine İlköğretimde, Görsel Sanatlar (1-8. Sınıflar) Dersinin kabulüne karar verilmiştir (MEB, 2006). Bu nedenle öğretim programlarında 2006 Öğretim programından itibaren "Resim-İş" dersi "Görsel Sanatlar" olarak değerlendirilmiştir.

\section{Bulgular}

Bu bölümde Türk Eğitim Sistemi’nde öğretim programlarında yer alan Görsel Sanatlar (Resim-İş) dersinin; programlardaki adı, hangi sınıf düzeylerinde yer aldığı, amaçları, kazanımları, ders saati ve öğretim programlarındaki ağırlığı ile ilgili bulgular ve yorumlara yer verilmiştir.

\section{Görsel Sanatlar (Resim-İş) Dersinin Programlardaki Adı}

Görsel Sanatlar dersinin öğretim programlarındaki adı ile ilgili gelişmeler Tablo 1'de yer almaktadır.

Tablo 1: Görsel Sanatlar (Resim-İş) Dersinin Programlardaki Adı İle İlgili Gelişmeler

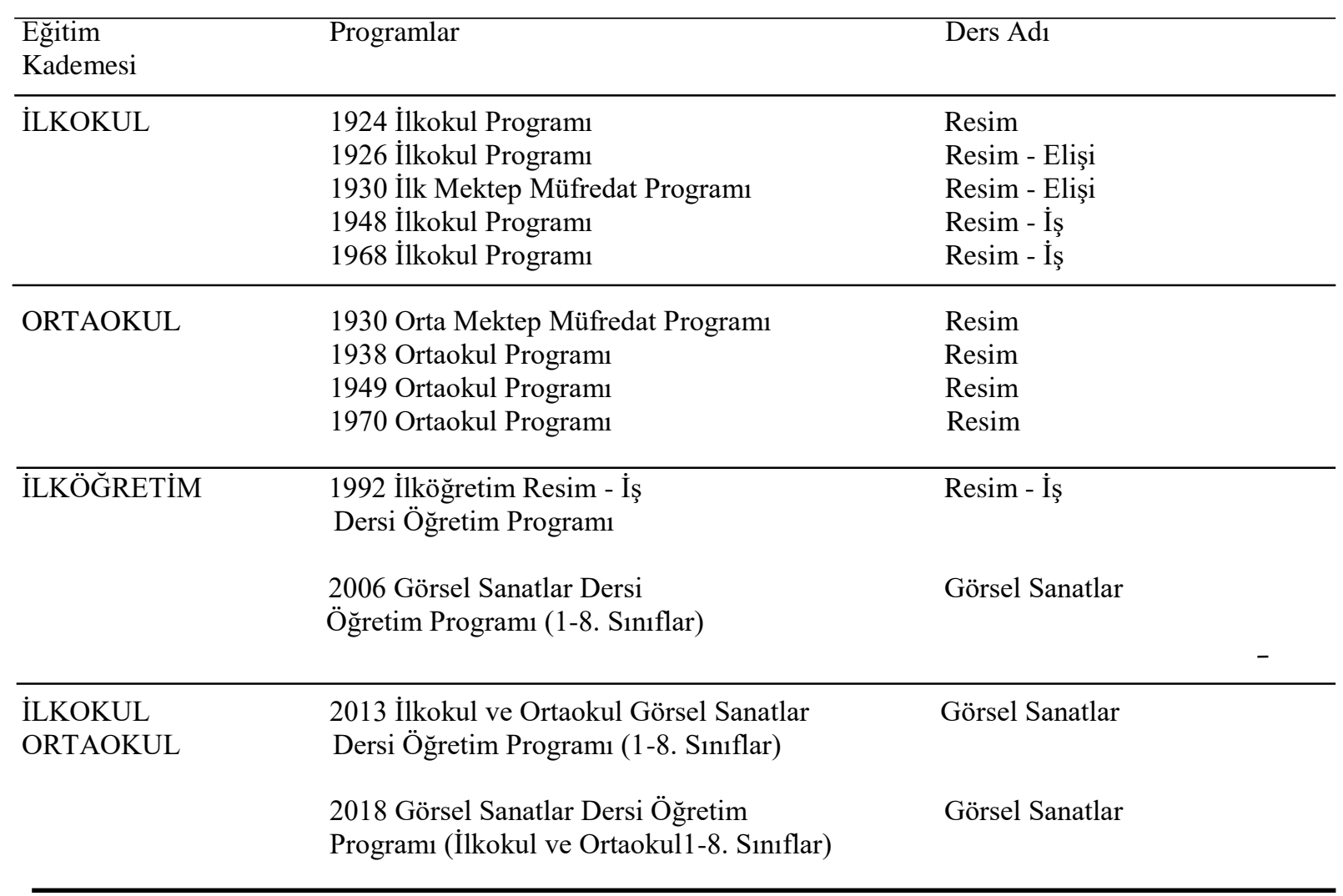

Tablo 1'de görüldüğü gibi Görsel sanatlar ile ilgili isim değişikliği 4 kez gerçekleştirilmiştir. Dersin adı, 1924 ilkokul ve 1930, 1938, 1949, 1970 ortaokul programlarında "Resim" olarak geçerken, 1926 ilkokul ve 1930 İlk Mektep programlarında "Resim-El İşi” olarak yer almıştır. 1948, 1968 ilkokul programlarında ve 1992 İlköğretim programında dersin adının “Resim-İş” olarak değiştirildiği görülmektedir. 2006 yılında Millî Eğitim Bakanlığı'nın yaptığı düzenleme ile "Resim-İş" dersi "Görsel Sanatlar" olarak öğretim programlarında yer almıştır. Ders aynı adla 2013 ve 2018 öğretim programlarında yerini almıştır. 


\section{Görsel Sanatlar (Resim-İş) Dersinin Sınıf Düzeylerindeki Durumu}

Görsel Sanatlar dersinin öğretim programlarındaki yeri ile ilgili gelişmeler Tablo 2'de yer almaktadır.

Tablo 2: Öğretim Programlarında Resim Dersinin Sınıf Düzeylerindeki Yeri İle İlgili Gelişmeler

\begin{tabular}{|c|c|c|}
\hline Eğitim & Programlar & Siniflar \\
\hline Kademesi & & $\begin{array}{llllllll}1 & 2 & 3 & 4 & 5 & 6 & 7 & 8\end{array}$ \\
\hline \multirow[t]{5}{*}{ İLKOKUL } & 1924 İlkokul Programı & $\boldsymbol{V} レ ル レ$ \\
\hline & 1926 İlkokul Programı & $\boldsymbol{V} レ レ レ$ \\
\hline & 1930 İlk Mektep Müfredat Programı & 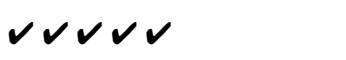 \\
\hline & 1948 İlkokul Programı & 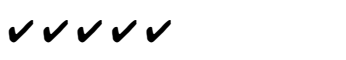 \\
\hline & 1968 İlkokul Programı & $\checkmark \checkmark \checkmark \checkmark \checkmark$ \\
\hline \multirow[t]{4}{*}{ ORTAOKUL } & 1930 Orta Mektep Müfredat Programı & $\boldsymbol{V} \boldsymbol{V}$ \\
\hline & 1938 Ortaokul Programı & $\boldsymbol{v} \boldsymbol{v}$ \\
\hline & 1949 Ortaokul Programı & $\boldsymbol{v} \sim \boldsymbol{v}$ \\
\hline & 1970 Ortaokul Programı & $\boldsymbol{v} レ$ \\
\hline \multirow[t]{2}{*}{ İLKÖĞRETİM } & $\begin{array}{l}1992 \text { İlköğretim Resim-İş } \\
\text { Dersi Öğretim Programı }\end{array}$ & 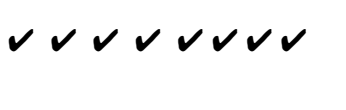 \\
\hline & $\begin{array}{l}2006 \text { Görsel Sanatlar Dersi } \\
\text { Öğretim Programı (1-8. Sınıflar) }\end{array}$ & $\checkmark \checkmark \checkmark \checkmark \checkmark \checkmark \checkmark \checkmark$ \\
\hline \multirow[t]{2}{*}{$\begin{array}{l}\text { İLKOKUL } \\
\text { ORTAOKUL }\end{array}$} & $\begin{array}{l}2013 \text { İlkokul ve Ortaokul Görsel Sanatlar } \\
\text { Dersi Öğretim Programı (1-8. Sınıflar) }\end{array}$ & $\checkmark v \vee v \vee v \sim v$ \\
\hline & $\begin{array}{l}2018 \text { Görsel Sanatlar Dersi Öğretim } \\
\text { Programı (İlkokul ve Ortaokul 1-8. Sınıflar) }\end{array}$ & $\checkmark v \checkmark v \checkmark v \checkmark v$ \\
\hline
\end{tabular}

Tablo 2'de görüldüğü gibi Görsel Sanatlar dersine Öğretim Programlarında ilkokul, ortaokul ve ilköğretim olmak üzere her sınıf düzeyinde yer verilmiştir. Bu durum sanat eğitimine önem verildiğini göstermektedir. 


\section{Görsel Sanatlar (Resim-İss) Dersinin Amaçları}

Görsel Sanatlar dersinin öğretim programlarındaki amaçları ile ilgili gelişmeler Tablo 3’te yer almaktadır.

Tablo 3: Görsel Sanatlar Dersinin Öğretim Programlarındaki Amaçları İle İlgili Gelişmeler

\begin{tabular}{|c|c|c|c|}
\hline & & PROGRAMLAR & AMAÇLAR \\
\hline \multirow{5}{*}{\multicolumn{2}{|c|}{ 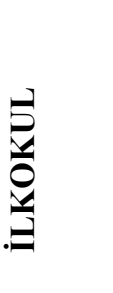 }} & 1924 İlkokul Programı & Ayrı başlık ya da başlıklar altında verilmemiştir. \\
\hline & & 1926 İlkokul Programı & 7 madde \\
\hline & & 1930 İlk Mektep Müfredat Programı & 7 madde \\
\hline & & 1948 İlkokul Programı & 9 madde \\
\hline & & 1968 İlkokul Programı & 7 madde \\
\hline \multirow{4}{*}{\multicolumn{2}{|c|}{ 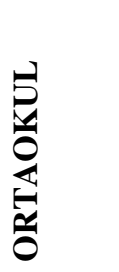 }} & 1930 Orta Mektep Müfredat Programı & Ayrı başlık ya da başlıklar altında verilmemiştir. \\
\hline & & 1938 Ortaokul Programı & 5 madde \\
\hline & & 1949 Ortaokul Programı & 7 madde \\
\hline & & 1970 Ortaokul Programı & 7 madde \\
\hline \multirow{5}{*}{\multicolumn{2}{|c|}{ 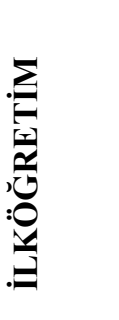 }} & 1992 İlköğretim Kurumları & 17 madde \\
\hline & & Resim-İş Dersi Öğretim Programı & \\
\hline & & 2006 Görsel Sanatlar Dersi & Bireysel ve toplumsal, algisal, estetik ve teknik \\
\hline & & Öğretim Programı (1-8. Sınıflar) & amaçlar olmak üzere dört gruba ayrılarak toplam 28 \\
\hline & & & madde ile ifade edilmiştir. \\
\hline \multirow{3}{*}{ 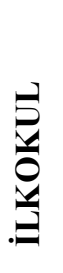 } & \multirow{3}{*}{ 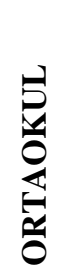 } & 2013 İlkokul Ve Ortaokul Görsel Sanatlar & 12 madde \\
\hline & & Dersi Öğretim Programı (1-8. Sınıflar) & \\
\hline & & $\begin{array}{l}2018 \text { Görsel Sanatlar Dersi Öğretim Programı } \\
\text { (İlkokul ve Ortaokul 1-8. Sınıflar) }\end{array}$ & 11 madde \\
\hline
\end{tabular}

1924 İlk Mektep Müfredat Programında "Resim” dersinin amaçlarına yer verilmemiştir. Amaçlar düzenli bir şekilde ilkokul ve dersler için hazırlanarak programda 1926 İlk Mektepler Müfredat Programı ile belirtilmiştir. Bu programda ilk kez "hedefler" bölümü maddeler halinde ayrıntılı bir şekilde yer almıştır (Aslan, 2011: 724). 1924 programda yer alan ders konuları, 1926 programında amaçlar başlığı altında verilmiştir. Programdaki amaçlar ardışıklık ilkesine uyum göstermektedir. Her bir madde bir önceki maddeyi destekler biçiminde basitten zora doğru sıralanmıştır. İlk maddede eşya ve renkleri görmeye alıştırmak verilmişsen bir sonraki maddede yaptıkları gözlemleri gölge ve boya ile tasvir etme amacına yer verilmiştir. 1930 İlk Mektep Müfredat Programında yer alan amaçlar, 1926 İlk Mektep Müfredat Programında 7 madde ile ifade edilmiştir. Amaçlarda herhangi bir değişiklik yapılmamıştır. 1948 İlkokul Programı daha önceki öğretim programlarından farklı olarak amaçları 9 madde ile açıklanmıştır. Programın amaçlarındaki yargılar geliştirmek, kazandırmak ve yardım etmek gibi ifadelere yer verilmiştir. Amaçların 3. maddesinde sanat eserlerinin öneminin kavranmasına ve sanat eserlerini diğer eserlerden ayırt edebilmesinin öğrenebilmesine vurgu yapılmıştır. Öğretim programlarında sanat derslerinde “estetik” ifadesi ilk kez 1948 ilkokul programının 2. maddesinde yer verilmiştir. Öğrencilerin kişiliklerinin bağımsızlığını kazanmalarına, sevgi ve saygı duygularını, yardımlaşma ve dayanışma alışkanlıklarını, çocukların kendi gizil güçlerinin farkına varmaları gibi gelişim özelliklerine göre amaçlar hedeflenerek öğretim programı planlanmıştır. 1968 programının amaçlarındaki yargılar “ifade eder, kazanırlar, geliştirirler, öğrenirler” olarak öğrenci kazanımlarına yönelik belirtilmiştir. Amaçlarda öğrencilerin değer yargılarını kavramaya, arttırmaya ve 
geliştirmeye yönelik ifadeler kullanılmıştır. Çevredeki artık maddelerden yeni bir şeyler üreterek geri dönüşüme destek verilmiş ve eşyaları olumlu yönde değerlendirmeleri hedeflenmiştir.

1930 Orta Mektep Müfredat Programında "Resim” dersinin amaçlarına yer verilmemiştir. 1938 Orta Mektep Müfredat Programının amaçlarında; öğrencinin gördüğünü yorumlama ve yaratıcılığını ortaya çıkararak yeniözgün resimler yapmasına yardımcı olabilmek üzerinde durulmuştur. 1938 ortaokul programında resim dersi hedeflerinin oldukça tutarlı olduğu, eğitimde yer alan bilişsel, duyuşsal ve psikomotor davranışlar kazandırma ögelerinin üzerinde durulmuştur. Amaçlarda resim dersi ile milli sanatlar arasında ilişki kurularak eserlerin; süsleme, şekil ve renklerinden yararlanılıp milli sanatlara verilen önem ve özelliklerin kavranması amaçlanmıştır. 1949-1970 programında amaçlardaki yargılar "kazandırmak, geliştirmek, sağlamak" olarak öğrenci kazanımlarına yönelik ifade edilmiştir. Amaçlarda öğrencilerin gözlemlerini, duygularını resim yoluyla anlatabilme yeteneğini kazandırmak üzerinde durulmuştur. Resim dersinin diğer derslerinde anlatımını kolaylaştıracak bir ders olarak işlenebileceğine değinilmiştir. Resim derslerin de öğrencilerin boş zamanlarını değerlendirmeleri ve zevkli-faydalı çalışmaların yapılmasıını destekleyici çalışmaların yapılması amaçlanmıştır.

1992 İlköğretim Resim-İş Dersi programında amaçlar, genel amaçlar başlığı altında 17 madde ile açıklanmıştır. Ayrıca dersin amaçları sınıf düzeylerine göre ayrıntılı olarak tek tek açıklanmıştır. 1992 Öğretim programında ders amaçları bütün sınıf düzeylerinde tek tek belirtilmiştir. Amaçlarda 1. sınıftan 5. sınıfa kadar daha çok araç-gereç bilgisi ve kullanabilme becerisi üzerinde yoğunlaşılmıştır. Derslerde ayrıca resim dersinin temel teknikleri olan çizgi, iki-üç boyutlu çalı̧̧malar ve renk bilgisine önem verilmiştir. 6.sınıftan itibaren kompozisyon, leke, karakalem ve doku gibi daha zor ve kapsamlı teknikler uygulanmıştır. Her sınıf düzeyinde tarihi yer, müze ve sanat eserlerinin değerine ve önemine vurgu yapılmıştır. Amaçlar, sınıf seviyelerine göre basitten zora doğru sıralanmıştır. 2006 Görsel Sanatlar Öğretim Programının amaçları 4 grup halinde belirtilmiştir. Bunlar; genel amaçlar, bireysel ve toplumsal amaçlar, algısal amaçlar, teknik ve estetik amaçlar olarak toplam 28 madde ile ayrıntılı ve açık bir şekilde açıklanmıştır. Amaçlar 1992 İlköğretim programına göre daha kapsamlı olarak ifade edilmiştir. Bireysel-Toplumsal ve algısal amaçlarda bilişsel ve duyuşsal davranışlara, estetik amaçlarda duyuşsal alana ilişkin davranışlar ve teknik amaçlarda ise genellikle psikomotor davranışlara yer verilmiş ayrıca duyuşsal ve bilişsel alana ilişkin davranışlar da belirtilmiştir. 2013 programının amaçlarındaki yargılar bireyin sanat eğitimine katkı sağlayacağı düşünülen ve bireyin kazanması gereken özellikler-değerler sıralanarak "sorgulayan, izleyen, koruyan, ilişkilendiren, aktaran" gibi ifadeler olarak verilmiş̧tir. 2013 öğretim programında bulunan "Çevresini inceleyen, çevreden esinlenen ve onu sonraki dönemlere aktaran" maddesi 2018 Öğretim programında bulunmamaktadır. 2013 programının 6. Maddesinde "Görsel sanatlara ait kültürel mirasın değerini bilen ve sanat eserlerini koruyan" maddesine ek olarak "Kendi kültürü ve diğer kültürlerin kültürel mirasın değerini anlayan ve onları koruyan" maddesi ile diğer kültürlere ait kültürel mirasın değerlerine de önem verilmesi vurgulanmıştır. Öğretim programlarında yer alan hedefler bölümünde; İlkokul ve Ortaokul öğretim programlarında fazla ayrıntıya yer verilmediği ve çok fazla değişiklik yapılmadığı görülmektedir. İlköğretim öğretim programlarında ise belirlenen hedeflerin daha fazla olduğu ve zamanla öğretim programlarında ayrıntıya daha fazla yer verildiği görülmektedir.

\section{Görsel Sanatlar (Resim-İş) Dersinin Kazanımları}

Kazanımlar, öğretim sürecinde öğrencilerin kazanacakları bilgi, beceri ve alışkanlıkları kapsamaktadır (MEB, 2006: 13). Kazanımlara ilk olarak 1992 yılındaki İlköğretim kurumları Resim-İş̧ dersi Öğretim Programında 1-8. sınıfların her sınıf düzeyinde yer verilmiştir. Burada 1992, 2006, 2013 ve 2018 İlköğretim öğretim programlarındaki kazanımlar ile ilgili gelişmeler yer almaktadır.

Tablo 4: 1992 İlköğretim Resim-İş̧ Dersi Öğretim Programı Kazanım Tablosu İle İlgili Bilgiler

\begin{tabular}{cccccccccc}
\hline \multicolumn{7}{c}{ Sinıflar } \\
\hline Kazanım Sayı1 & 1 & 2 & 3 & 4 & 5 & 6 & 7 & 8 & Toplam \\
\hline & 125 & 171 & 178 & 111 & 118 & 164 & 153 & 116 & 1136 \\
\hline
\end{tabular}

(MEB, 1992: 21-144)

* 1992 Öğretim Programı Öğrenme alanlarına ayrılmamıştır.

Tablo 4 'te görüldüğü gibi en fazla kazanıma 178 ile 3. sınıfta, en az kazanıma ise 111 ile 4.sınıfta yer verilmiştir. İlköğretimde hedeflenen toplam kazanım sayısı 1136 olduğu görülmektedir. Tabloda hedef sayılarında farklılıklar olduğu; ara sınıflarda arttığı üst sınıf düzeylerinde ise kazanımların azaldığı görülmektedir. 
Tablo 5: 2006 Görsel Sanatlar Dersi Öğretim Programı Kazanım Tablosu İle İlgili Bilgiler

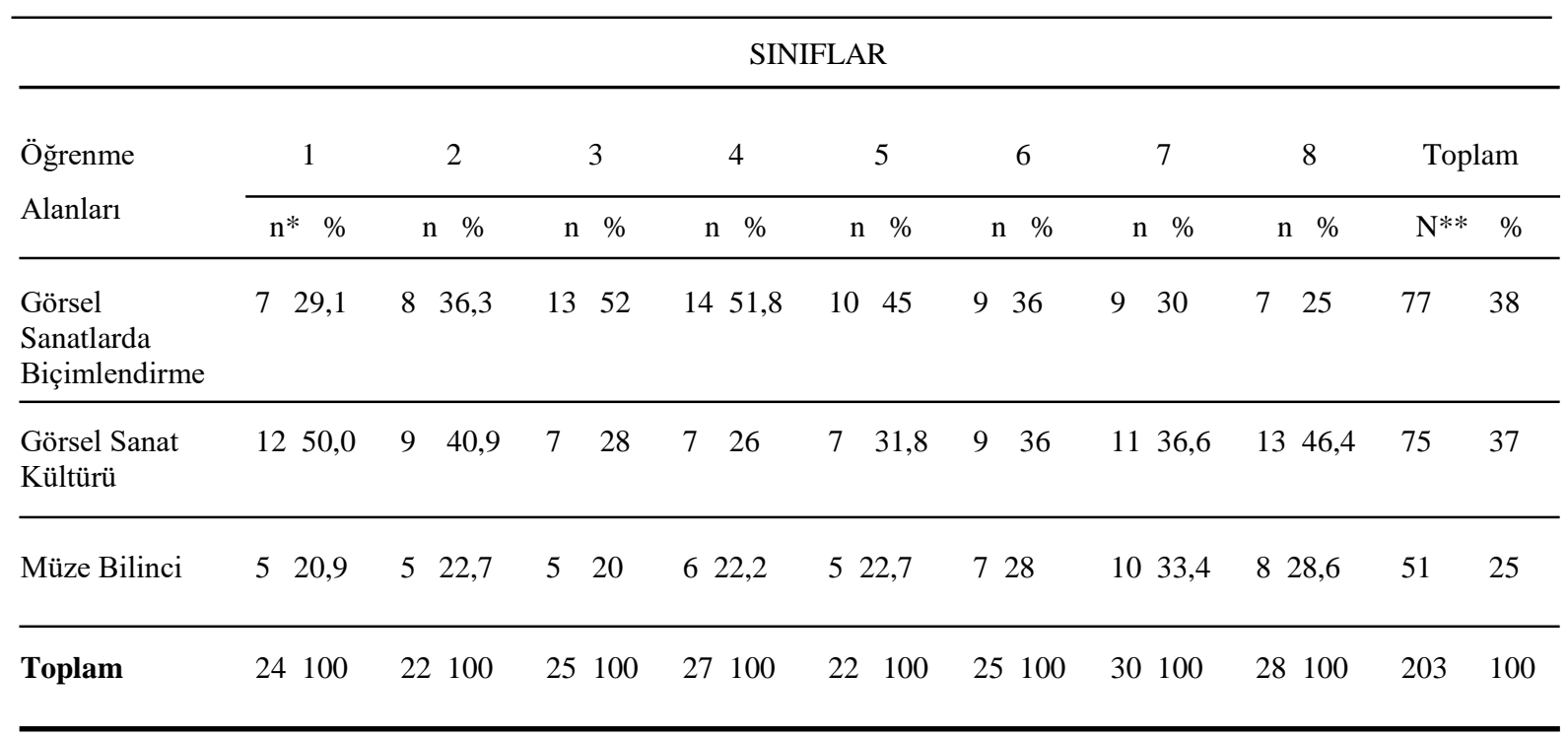

(MEB, 2006: 33-70)

* $\mathrm{n}$ : Kazanım Sayısı

** N: Toplam Kazanım Sayısı

Tablo 5’te görüldüğü gibi 2006 Görsel Sanatlar Dersi Öğretim Programı 3 öğrenme alanı olan "Görsel Sanatlarda Biçimlendirme", "Görsel Sanat Kültürü” ve "Müze Bilinci” olarak yapılandırılmıştır. Kazanım ağırlıkları incelendiğinde sınıf düzeylerinde zamanla artış olduğu görülmektedir. Toplam kazanım sayısına oranla öğrenme alanlarında Görsel Sanatlarda Biçimlendirme alanında en fazla 3.sınıfta 13 kazanım ile (\% 52), Görsel Sanat Kültürü alanında en fazla 1 .sınıfta 12 kazanım ile (\% 50) ve Müze bilinci alanında en fazla 7.sınıfta 10 kazanım ile $(\% 33,4)$ görülmektedir. Kazanımların alanlara göre toplam sıralamasında en fazla kazanımın ilk sırada Görsel Sanatlarda Biçimlendirme alanında 77 kazanım ile (\% 38), ikinci sırada Görsel Sanat Kültürü 75 kazanım ile (\% 37) ve son sırada Müze Bilinci 51 kazanım ile (\% 25) yer almaktadır.

Tablo 6: 2013 Görsel Sanatlar Dersi Öğretim Programı Kazanım Tablosu İle İlgili Bilgiler

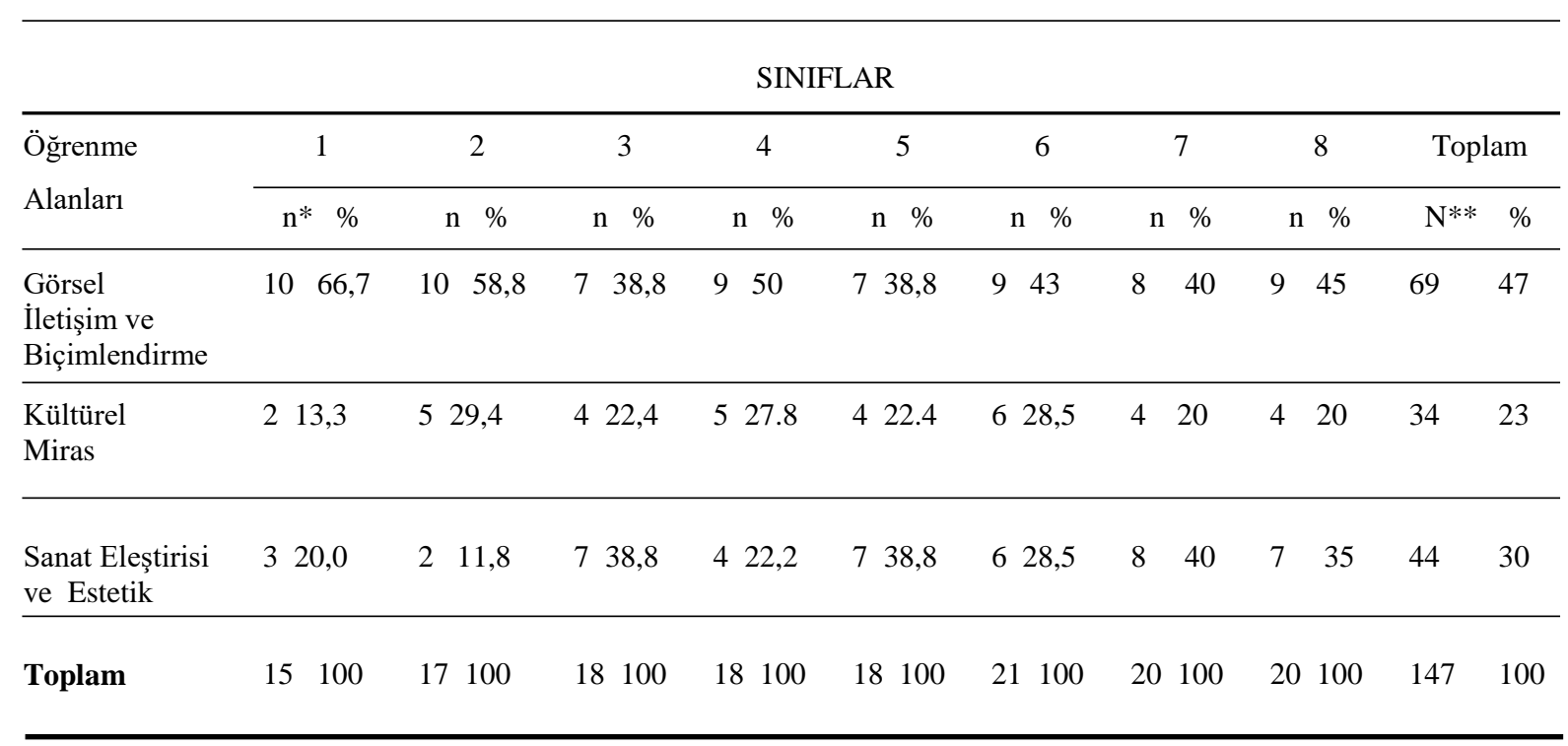

(MEB, 2013: 8)

* $\mathrm{n}$ : Kazanım Sayısı

** N: Toplam Kazanım Sayısı 
Tablo 6'da görüldüğü gibi 2013 Görsel Sanatlar Dersi Öğretim Programı 3 öğrenme alanı olan “Görsel İletişim ve Biçimlendirme", "Kültürel Miras” ve "Sanat Eleştirisi ve Estetik” olarak yapılandırılmıştır. Kazanım ağırlıkları incelendiğinde sınıf düzeylerinde zamanla artış olduğu görülmektedir. Toplam kazanım sayısına oranla öğrenme alanlarında Görsel İletişim ve Biçimlendirme alanında en fazla 1. sınıfta 10 kazanım (\% 66,7), Kültürel Miras alanında en fazla 6. sınıfta 6 kazanım $(\% 28,5)$ ve Sanat Eleştirisi ve Estetik alanında ise en fazla 7.sınıfta 8 kazanım (\% 40) görülmektedir. Kazanımların alanlara göre toplam sayılarında en fazla kazanımın Görsel İletişim ve Biçimlendirme alanında 69 (\% 47), ikinci sırada Sanat Eleştirisi ve Estetik 44 (\% 30) ve son sırada Kültürel Miras 34 (\% 23) yer almaktadir.

Tablo 7: 2018 Görsel Sanatlar Dersi Öğretim Programı Kazanım Tablosu İle İlgili Bilgiler

\begin{tabular}{|c|c|c|c|c|c|c|c|c|c|c|c|c|c|}
\hline \multirow{3}{*}{$\begin{array}{l}\text { Öğrenme } \\
\text { Alanları }\end{array}$} & \multicolumn{11}{|c|}{ SINIFLAR } & \multirow{2}{*}{\multicolumn{2}{|c|}{ Toplam }} \\
\hline & 1 & 2 & 3 & \multicolumn{2}{|r|}{4} & 5 & 6 & \multicolumn{2}{|r|}{7} & \multicolumn{2}{|r|}{8} & & \\
\hline & $\mathrm{n} * \%$ & $\mathrm{n} \%$ & $\mathrm{n} \%$ & $\mathrm{n}$ & $\%$ & $\mathrm{n} \%$ & $\mathrm{n} \%$ & $\mathrm{n}$ & $\%$ & & $\%$ & $\mathrm{~N}^{* *}$ & $\%$ \\
\hline $\begin{array}{l}\text { Görsel } \\
\text { İletişim ve } \\
\text { Biçimlendirme }\end{array}$ & $10 \quad 66,7$ & 1058,8 & $7 \quad 41,2$ & 7 & 43,7 & 736,8 & 942,8 & 8 & 40 & 9 & 45 & 67 & 47 \\
\hline $\begin{array}{l}\text { Kültürel } \\
\text { Miras }\end{array}$ & 213,3 & 529,4 & 317,6 & 5 & 31,3 & 526,3 & 628,6 & 4 & 20 & 4 & 20 & 34 & 23 \\
\hline $\begin{array}{l}\text { Sanat Eleştirisi } \\
\text { ve Estetik }\end{array}$ & 320,0 & 211,8 & 741,2 & 4 & 25 & 736,8 & 628,6 & 8 & 40 & 7 & 35 & 44 & 30 \\
\hline Toplam & $15 \quad 100$ & 17100 & 17100 & 16 & 100 & 19100 & 21100 & 20 & 100 & 20 & 100 & 145 & 100 \\
\hline
\end{tabular}

(MEB, 2018: 13)

* $\mathrm{n}$ : Kazanım Sayısı

** N: Toplam Kazanım Sayısı

Tablo 7'de görüldüğü gibi 2018 Görsel Sanatlar Dersi Öğretim Programı 3 öğrenme alanı olan “Görsel İletişim ve Biçimlendirme" , "Kültürel Miras” ve "Sanat Eleştirisi ve Estetik” olarak yapılandırılmıştır. Kazanım ağırlıkları incelendiğinde sınıf düzeylerinde zamanla artış olduğu görülmektedir. Toplam kazanım sayısına oranla öğrenme alanlarında en fazla 1.sınıfta Görsel İletişim ve Biçimlendirme alanında 10 kazanım (\% 66,7) görülmektedir. Kültürel Miras alanında en fazla 4.sınıfta 5 kazanım (\% 31,3) ve Sanat Eleştirisi ve Estetik alanında ise en fazla 3.sınıfta 7 kazanım (\% 41,2) görülmektedir. Kazanımların alanlara göre toplam sayılarında en fazla kazanımın Görsel İletişim ve Biçimlendirme alanında 67 (\% 47), ikinci sırada Sanat Eleştirisi ve Estetik 44 (\% 30) ve son sırada Kültürel Miras 34 (\% 23) yer almaktadır. 


\section{Görsel Sanatlar (Resim-i̇ş) Dersinin Ders Saatleri}

Tablo 8 : Öğretim Programlarında Resim Dersinin Değişen Ders Saatleri İle İlgili Bilgiler

\begin{tabular}{|c|c|c|c|c|c|c|c|c|c|c|}
\hline Eğitim & Programlar & \multicolumn{9}{|c|}{ Siniflar } \\
\hline \multicolumn{2}{|l|}{ Kademesi } & 1 & 2 & 3 & 4 & 5 & 6 & 7 & 8 & \\
\hline \multirow[t]{6}{*}{ İLKOKUL } & 1924 İlkokul Programı (Kızlar-Erkekler) & 2 & 2 & 2 & 2 & 2 & & & & \\
\hline & & 2 & 2 & 2 & 2 & & & & & \\
\hline & 1926 İlkokul Programı & 4 & 4 & 4 & 3 & & & & & \\
\hline & 1930 İlk Mektep Müfredat Programı & 4 & 4 & 4 & 2 & & & & & \\
\hline & 1948 İlkokul Programı & 4 & 4 & & 2 & & & & & \\
\hline & 1968 İlkokul Programı & 1 & 1 & 1 & 2 & 2 & & & & \\
\hline \multirow[t]{5}{*}{ ORTAOKUL } & 1930 Orta Mektep Müfredat Programı & & & & & & 2 & & & 1 \\
\hline & 1938 Ortaokul Programı (Kılar-Erkekler) & & & & & & 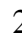 & & 1 & 1 \\
\hline & & & & & & & & & 1 & 1 \\
\hline & 1949 Ortaokul Programı & & & & & & 1 & & 1 & 1 \\
\hline & 1970 Ortaokul Programı & & & & & & & & 1 & 1 \\
\hline \multirow[t]{2}{*}{ İLÖĞRETİM } & $\begin{array}{l}1992 \text { İlköğretim Resim-İş } \\
\text { Dersi Öğretim Program }\end{array}$ & 2 & 2 & 2 & 2 & 2 & 1 & & & 1 \\
\hline & $\begin{array}{l}2006 \text { Görsel Sanatlar Dersi } \\
\text { Öğretim Programı (1-8. Sinıflar) }\end{array}$ & 2 & 2 & 2 & 2 & 2 & 1 & & 1 & 1 \\
\hline \multirow[t]{2}{*}{$\begin{array}{l}\text { İLKOKUL } \\
\text { ORTAOKUL }\end{array}$} & $\begin{array}{l}2013 \text { İlkokul ve Ortaokul Görsel Sanatlar } \\
\text { Dersi Öğretim Programı (1-8. Sinıflar) }\end{array}$ & 1 & 1 & 1 & 1 & 1 & 1 & & 1 & 1 \\
\hline & $\begin{array}{l}2018 \text { Görsel Sanatlar Dersi Öğretim } \\
\text { Programı (İlkokul ve Ortaokul1-8. Sınıflar) }\end{array}$ & 1 & 1 & 1 & 1 & 1 & & & 1 & 1 \\
\hline
\end{tabular}

Tablo 8'de görüldüğü gibi Öğretim Programlarında "Görsel Sanatlar" dersi 1924 ilkokul öğretim programında resim dersi kız ve erkek öğrenciler grubunda haftalık her sınıf düzeyi için 2 ders saati olarak yer almaktadır. Kız ve erkek öğrenciler için resim ders saatleri arasında farklılık görülmemektedir. 1926 ilkokul öğretim programında 1., 2. ve 3. sınıfta 4 ders saati, 4. ve 5. sınıfta 3 ders saati olarak yer almıştır. 1930 ve 1948 İlkokul öğretim programlarında 1 ., 2. ve 3 . sinıflarda 4 ders saati, 4 . ve 5 . sınıflarda 2 ders saati olarak verilmiştir. 1968 İlkokul programında 1., 2. ve 3. sınıflarda ders saatleri önceki öğretim programlarına göre azaltılmıs 1 ders saati olarak yer verilmiştir. 4 . ve 5 . sınıflarda 2 ders saati olarak değişikliğe gidilmemiştir.

1930 Ortaokul öğretim programında "Resim-İ̧s" dersi 6. ve 7. sınıfta 2; 8. sınıfta 1 ders saati olarak görülmektedir. 1938 Ortaokul öğretim programı erkek ve kızlar olarak ayrılmıştır. Erkek öğrencilere 6. sınıfta 2, 7 ve 8. Sınıfta 1 ders saati; Kız öğrencilere her sınıf düzeyinde 1 ders saati verilmiştir. 1924 İlk Mektepler Müfredat Programında ve 1938 Ortaokul programlarında erkek ve kız ayrımı yapılmadan tek program olarak hazırlanmıştır. Ders çizelgeleri erkek ve kız olarak ayrı verilmiştir. Ayrı olarak verilmesinin nedeni bazı derslerin erkekler için bazı derslerin ise kızlar için programda bulunmuş olması ve ders saatlerinin de farklı olmasından kaynaklanmaktadır (Aslan, 2011: 724). 1949 ve 1970 Ortaokul öğretim programında "Resim" dersine her sınıf düzeyinde 1 ders saati yer verilmiştir.

1992 İlköğretim programında 1., 2., 3., 4. ve 5. sınıfta 2 ders saati , 6., 7. ve 8. sınıfta 1 ders saati, 2006 Görsel Sanatlar öğretim programında 1., 2. ve 3. sınıfta 2 ders saati, diğer sınıflarda 1 ders saati verilmiştir. 2013 ve 2018 Görsel Sanatlar öğretim programında diğer programlara göre gittikçe azalan ders saati daha da azaltılarak her sınıf düzeyinde 1 ders saati verilmiştir. "Resim -İş" dersine 1924 ten 1948 İlkokul programlarına kadar daha fazla ders saati verilmiştir. Bu durum daha sonraki yıllarda ilkokul ve ortaokul programlarında zamanla azalmıştır. 


\section{Görsel Sanatlar Dersinin Öğretim Programlarındaki Ağırlığı İle İlgili Gelişmeler}

Görsel Sanatlar dersinin öğretim programlarındaki ağırlığı ile ilgili gelişmeler Tablo 9'da yer almaktadır.

Tablo 9 : Öğretim Programlarında Resim Dersinin Öğretim Programlarındaki Ağırlığı İle İlgili Gelişmeler

\begin{tabular}{|c|c|c|c|}
\hline $\begin{array}{l}\text { EĞiTiM } \\
\text { KADEMESI }\end{array}$ & PROGRAMLAR & $\begin{array}{c}\text { PROGRAMDAKI } \\
\text { TOPLAM } \\
\text { DERS SAATI }\end{array}$ & $\begin{array}{c}\text { RESIM } \\
\text { DERSI TOPLAM } \\
\text { DERS SAATI }\end{array}$ \\
\hline
\end{tabular}

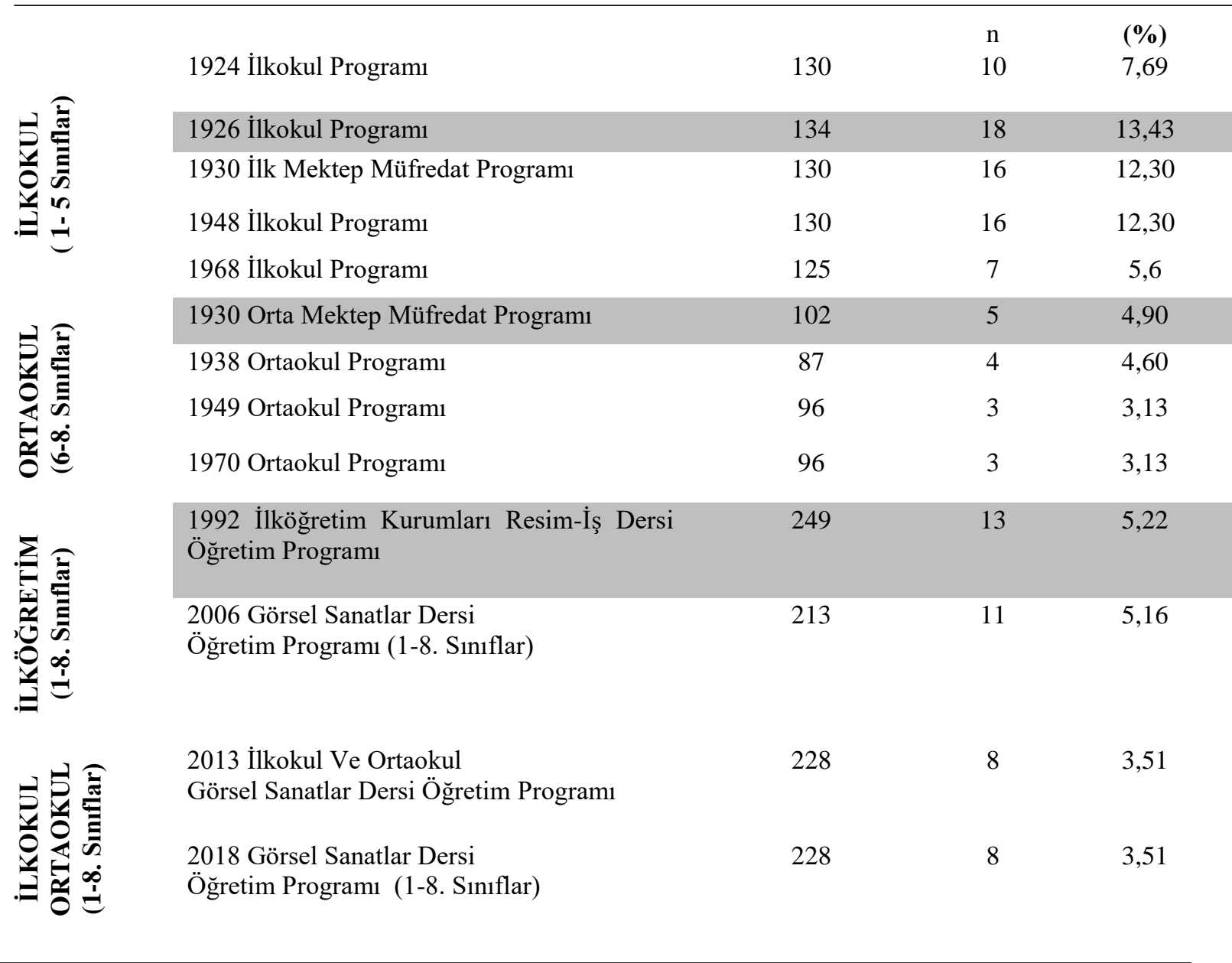

Tablo 9'da görüldüğü gibi Resim dersinin öğretim programlardaki ağırlığı incelendiğinde ilkokul programlarında 1926 da ilk sirada yer almaktadır. Programda derse 134 toplam ders saatinden 18 saat $(\% 13,43)$ resim dersine yer verilmiştir. $\mathrm{Bu}$ durum ilk dönemler sanata daha fazla değer verildiğini göstermektedir. Ortaokul programlarında en fazla 1930 öğretim programında 102 toplam ders saatinden 5 saat $(\% 4,90)$ verilmiştir. İlköğretim programlarında ise 249 toplam ders saatinden en fazla 1992 öğretim programında 13 saat $(\% 5,22)$ yer verilmiştir. Programları incelediğimizde Resim dersinin diğer derslere göre programlardaki ağırlığı zamanla azalmıştır.

\section{Sonuçlar}

Araştırmada Görsel Sanatlar dersinde İlkokul, Ortaokul ve İlköğretim düzeyinde dersin adında değişiklikler yapıldığı görülmüş̧ür. Görsel Sanatlar dersi, Öğretim programlarında "Resim”, "Resim-Elişi”, "Resim - İş" ve son olarak 2006 öğretim programlarından itibaren "Görsel Sanatlar" olarak değiştirilmiştir.

Görsel sanatlar dersi Öğretim programlarında ilkokul, ortaokul ve ilköğretim olmak üzere her sınıf düzeyinde yer verilmiştir. Resim dersi bireye bakış açısı kazandırarak çok yönlü düşünmesini sağlar ve hayal gücünü genişletir. Bireye küçük yaşlardan itibaren çevreyi anlamak, sanatı sevdirmek ve anlamak için resim dersinin verilmesi oldukça önemlidir. Görsel sanatlar dersi ilkokuldan başlayarak, ortaokul ve ilköğretimde uygun teknik ve yöntemlerle çalışılan, ayrıca sanat tarihi - tarihçileri bilgisiyle desteklenen bir ders konumundadır. 
Programların amaçları incelendiğinde; geçmişten günümüze amaçlara yer verilmiş amaçlarda hedef sayısı bakımından artış görülmektedir. 1924 ilkokul ve 1930 ortaokul programlarında amaçlara yer verilmemiştir. 1926 ilkokul programında ilk kez amaçlara maddeler halinde yer verildiği ve amaçların öğretmen davranışına yönelik olduğu belirlenmiştir. 1930, 1948 ve 1968 ilkokul programlarında da fazla değişiklik yapılmadığı aynı programın uygulandığı belirlenmiştir. İlk kez estetik ifadesine 1948 programında yer verilmiştir. 1968 programında amaçların öğrenci kazanımına yönelik belirlendiği belirlenmiştir. Ortaokul programlarında ise, 1938 ortaokul programında 5 madde ile açıklanmış amaçlarda milli sanatlara önem verilmesi hedeflenmiştir. 1949 ve 1970 programlarında pek fazla değişiklik yapılmadan uygulamaya devam edilmiştir. İlköğretim programı olarak uygulamaya konan ve kitap olarak çıkarılan 1992 Resim-iş dersi öğretim programı daha kapsamlı, ayrıntılı bir şekilde planlanmıştır. Programda genel amaçlara yer verilmiş ve her sınıf düzeyine göre amaçlar tek tek belirlenmiştir. 2006 öğretim programının amaçları 4 gruba ayrılarak ayrıntılı ve açık bir şekilde belirtilmiştir. 2013 ve 2018 programı önceki programlar gibi maddeler halinde açıklanmış ve 2018 programında daha çok kendi kültürümüzün önemine değinilmiştir. Programlarda derslerle ilgili hedefler açık, anlaşılır ve öğrenci davranışına yönelik yazılmadığı sürece uygulayıcıya kolaylık sağlamaz ve hedeflerin yorumlanışı öğretmenden öğretmene farklılık gösterir.

Programlardaki öğrenciye hedeflenen kazanımlara ilk kez 1992 ilköğretim programında yer verilmiştir. Kazanımlar programlarda sınıf düzeylerine göre belirlenmiş ve öğrenme alanlarına göre yapılandırılmıştır. Görsel sanatlarda biçimlendirme alanında dersin temelini oluşturduğunda daha fazla kazanım hedeflenmiştir. Araştırmada günümüz programlarında görsel sanatlar dersi için belirlenen ders saatinin hedeflenen kazanımların planlanmasının ve uygulanmasının yetersiz olduğunu göstermektedir.

Görsel sanatlar dersinin ders saati ile ilgili gelişmeler incelendiğinde haftalık ders saati çizelgelerinde ilkokul, ortaokul ve ilköğretim öğretim programlarında her sınıf düzeyinde yer verilmiştir. İlk program olan 1924 ve 1938 öğretim programında kız ve erkek olmak üzere program hazırlanmış 1924 programında ders saatleri değişmemiş 1938 programında ise kızlara daha az ders saati verilmiş bunun nedeni ise kızlara biçki dikiş, ev idaresi ve çocuk bakımı gibi derslerin verilmesi olarak belirtilmiştir. Resim dersine ilk yıllarda özellikle 1926 ilkokul öğretim programında fazla ders saati verildiği bu durumun daha sonraki yıllarda zamanla azaldığı görülmekte ve derse önemin giderek azaldığı belirlenmiştir. Sanat eğitimi; özellikle ilköğretim dönemlerinde öğrenme ve gelişsim sürecinde bireye kazandırılması düşünülen; kendini ifade edebilen, işbirliği içinde çalışabilen, üretken, kolay kavrayabilen, duygu düşüncelerini aktarabilen, yeteneklerini estetik seviyeye yükseltmek için yapılan öğretim faaliyetleridir.

Görsel sanatlar dersinin programlardaki ağırlığını incelediğimizde geçmişten günümüze ilk zamanlarda resim dersi ilk zamanlarda 18 saat $(\% 13,43)$ ile yer alırken günümüz programlarında 8 saat $(\% 3,51)$ ile zamanla arka planda bırakılmıştır. Görsel sanatlar bireyin sosyalleşmesini sağlar. Dersin yaparak yaşayarak uygulanması ile öğrendiklerini kalıcılığını destekler. Bireyin yaratıcılıklarını ön plana çıkarır, görsel zekasının gelişimine katkı sağlayarak gördüğünü yorumlar ve yeni fikirler ortaya çıkarır. Ayrıca bireyin psikomotor becerilerinin gelişmesine katkı sağlar. Öğretim programlarında belirlenen kazanımlara ulaşılabilmesi için dersin programlardaki ağırlığı arttırılmalı ve programlarda görsel sanatlara daha fazla ders saati verilmesi sağlanmalıdır.

\section{Öneriler}

Türkiye'de sanat eğitiminin öğretim programlarındaki yerine baktığımızda, birçok değişiklikler ve gelişmeler olduğu gözlenmektedir. Zorunlu eğitimde özellikle sanat eğitiminin hak ettiği ağırlığı yakalaması ve gelişmesi için sanat eğitimine önem verilmeli ve desteklenmelidir.

Görsel Sanatlar dersi öğretim programı Resim dersi öğretim programına oranla daha kapsamlı ve daha ayrıntılı olduğundan ders adı ve içeriğinin Görsel Sanatlar olarak devam etmesi daha uygun olacaktır.

Sanat eğitimi bireye duygu ve düşüncelerini ortaya çıkarmasında yardımcı olur. Sanat eğitiminin amacı, bireylerin yeteneklerinin, yaratıcılıklarının ve kişiliklerinin geliştirilmesi; estetik duyarlılığının belirli bir düzeye ulaşılması için yapılan çaba olduğundan; özellikle Görsel Sanatlar dersinin programlarda belirlenen amaçlara ulaşılabilmesi ve hedeflenen kazanımların uygulanabilmesi için ders saatinin arttırılması gerekmektedir.

Öğretim programlarında görsel sanatlara diğer derslere oranla zamanla azalan ağırlığı arttırılarak derse gerekli önem verilmelidir.

\section{Kaynakça}

Akkurt, S. ve Boratav, O. (2018). Neden sanat eğitimi?. Uluslararası Ĕ̆itim Araştırmacıları Dergisi, 1(1), 54-60. 
Akpınar, B. (2017). Eğitimde program geliștirme ve değerlendirme. Ankara: Data Yayınları.

Aslan, E. (2011). The first primary school curriculum of the turkish republic:"1924 İlk mektepler müfredat programı" Elementary Education Online, 10(2), 717-734.

Artut, K. (2013). Sanat eğitimi kuramları ve yöntemleri. Ankara: Anı Yayıncılık.

Aşılıoğlu, B. ve Diğerleri. (2014). Öğretim ilke ve yöntemleri. Ankara: Anı Yayıncılık.

Ayaydın, A. (2015). Çoklu zekâ tabanlı görsel sanatlar eğitimi. Ankara: Nobel Yayıncılık.

Ayaydın, A, ve Diğgerleri. (2011). Sanat eğitimi ve görsel sanatlar eğitimi, (Ed.: Ali Osman Alakuş ve Levent Mercin ). Ankara: Pegem Akademi Yayınları.

Buyurgan, S, ve Buyurgan, U. (2012). Sanat eğitimi ve ögretimi. Ankara: Pegem Akademi Yayınları.

Demirel, Ö. (2015). Kuramdan uygulamaya eğitimde program geliştirme. Ankara: Pegem Akademi.

Fidan, N. (2012). Okulda öğrenme ve ögretme. Ankara: Pegem Akademi Yayınları.

Gültekin, M. ve Diğ. (2017). Program gelişstirmeye ilişkin temel kavramlar. eğitimde program geliştirme ve değerlendirme içinde, (Ed.: Behçet Oral ve Taha Yazar ). Ankara: Pegem Akademi Yayınları.

Gürkan, T. ve Diğ. (1998). Eğitim bilimine giriş, (Ed.: Fatma Varış).İstanbul: Alkım Yayınları.

Kırışoğlu, O. T. ( 2005). Sanatta eğitim, görmek, ögrrenmek, yaratmak. Ankara: Pegem Akademi Yayınları.

MEB. (1992). Illköğretim kurumları resim-iş dersi ögrretim programı. Ankara: Milli Eğitim Basımevi.

MEB. (2006). Görsel sanatlar dersi ögretim programı ( 1-8. Sinfflar).

MEB. (2013). Illkokul ve ortaokul görsel sanatlar dersi öğretim programı (1 - 8. Sinuflar).

MEB.(2018). (http://mufredat.meb.gov.tr/ProgramDetay.aspx?PID=358 ).

Mercin, L., ve Alakuş, A.,O. (2007). Birey ve toplum için sanat eğitiminin gerekliliği, Dicle Üniversitesi Ziya Gökalp Ĕgitim Fakültesi Dergisi, 9,s.14-20.

Merriam, S. B. (2015). Nitel araştırma: desen ve uygulama için bir rehber, (Çev. Ed.: Selahattin Turan). Ankara: Nobel Yayincilik.

Özsoy, V. (2015). Görsel sanatlar eğitimi. Ankara: Pegem Akademi Yayınları.

Şeker, H. ve Diğ. (2014). Eğitimde program geliş̧tirme, (Ed.: Hasan Şeker), Ankara: Anı Yayıncılık

Şişman, M. (2018). Eğitime giriş. Ankara: Pegem Akademi.

Tan, Ş. ve Erdoğan, A. (2004). Öğretimi planlama ve değerlendirme, Ankara: Pegem Akademi Yayınları.

Ünver, E. (2002). Sanat eğitimi. Ankara: Nobel Yayınc1lı.

Yıldırım, A., ve Şimşek, H. (2016). Sosyal bilimlerde nitel araştırma yöntemleri. Ankara: Seçkin Yayıncılık.

Yolcu, E. (2018). Sanat eğitimi kuramlarl ve yöntemleri. Ankara: Pegem Akademi.

\section{Extended Abstract}

The contribution of art education to the necessity in the development of the individual, its impact upon creativity, and its contribution to the achievements which are realized in psychomotor, cognitive and affective fields are quite crucial. In art education besides the cultural and social contributions of art to the individual, the development of individuals who are self-confident, revealing their talents, develop their environmentally sensitive and aesthetic feelings are given importance. Education should be in harmony with science and art in coopreation. Art education has taken its place as a part of education with names such as painting, painting-work, painting-handiwork and visual arts in the education programs with the name changing and course hour in every education stage. In this study; the aim is to evaluate the developments in the Visual Arts curriculum in the Turkish Education System (1924 - 2018), in the direction of the research purpose, qualitative research approach is adopted, the model of the research is the method of screening the source. In the study, Visual Arts subject programs between 1924 and 2018 were scanned and the visual name of the visual arts, the number of subject hour, which classes they took part, the developments related to the target and the weight of the visual arts in the programs according to the other courses 
were assessed. As the screening model was used in the study, the universe and sample were not mentioned. In the consequence of the research, the subject name has changed over time as Visual Arts since 2006 and it has been determined that the subject is given in each class level and the number of subject hours has been insufficient compared to the ones started with 4 hours and continues with 1 lesson hour in proportion to the learning outcomes since 2013. It has been seen that the most detailed program in which the aims and content elements were included in all programs were 1948 elementary school and 2006 primary education programs. The targeted achievements of the students in the programs were first included in the 1992 primary education program. Achievements were determined according to class levels in the programs and structured according to learning areas. When it is the basis of the course in the field of formatting in visual arts, more gains are aimed. The research shows that the subject hours determined for the visual arts subject in today's programs are inadequate in the planning and implementation of the targeted gains. When we examine the weight of the visual arts subject in the programs from the past to the present, the first time the painting lesson took place in the first place with 18 hours (13.43\%), while today's programs were left behind in the background with 8 hours $(3.51 \%)$. Visual arts allow the individual to socialize. It emphasizes the creativity of the individual, contributes to the development of visual intelligence, interprets what it sees and creates new ideas. It also contributes to the development of an individual's psychomotor skills. The weight of the subject should be increased and visual arts should be given more hours in the programs in order to reach the objectives determined in the curriculum. 